\title{
EFFECT OF GENDER DIFFERENCES AND OTHER FACTORS ON REMUNERATION OF EMPLOYEES IN EU COUNTRIES
}

\author{
Irena Antošová ${ }^{1}$, Nad'a Hazuchová ${ }^{2}$, Jana Stávková ${ }^{3}$
}

\begin{abstract}
The aim of the paper is to verify gender income differences and to reveal factors influencing differences in remuneration. Gender income differences across the EU range from $6 \%$ in Romania to $27 \%$ in the Czech Republic. Data from 178,878 employees filtered from the EU-SILC database were used for calculations. Stepwise regression analysis was used to identify factors that affect gender income differences. The greatest effect was shown in the "Absolute Income", then the "Job Change in the Last Year" factor, but the "Education" and "Age" showed a strongly negative tendency. Extraordinary attention is devoted to the effect of the "Job sector" factor, which also significantly contributes to the difference in income. Different representation of gender appears in different industries, which can be caused by preferences and be a consequence of persisting society-wide stereotypes. Social policies are not in line with changes in society and lag behind the development of society.
\end{abstract}

\section{Keywords}

Job Remuneration, Income, Gender Pay Gap, Job Sector, EU-SILC

\section{Introduction}

The level of income or salary of employee households determines their income situation, which is one of the basic factors determining their living standard. Gender income differences in the context of a position of women in societies are discussed around the world, including EU countries.

The aim of the article is to verify discussed gender differences in income from employment, i.e. in wages and salaries among men and women in all EU countries. Above all, the aim is to identify factors which cause gender differences in employment remuneration, including the size of the effect of individual factors. The assessed factors are demographic and socio-economic characteristics of the individual, and factors applying to employment job sector, type of employment contract, number of months of performed work and others.

\footnotetext{
${ }^{1}$ Mendel University in Brno, Zemědělská 1, 61300 Brno, Czech Republic. E-mail: irena.antosova@mendelu.cz.

${ }^{2}$ Mendel University in Brno, Zemědělská 1, 61300 Brno, Czech Republic. E-mail: nada.hazuchova@mendelu.cz.

${ }^{3}$ Mendel University in Brno, Zemědělská 1, 61300 Brno, Czech Republic. E-mail: jana.stavkova@mendelu.cz.
} 
Data available from the EU-SILC database makes it possible to focus on the effect of the factors in more detail. Special attention is paid to the "Job sector" factor. This is a factor where historically in society there is a display of ongoing awareness of typically male and female industries. The research question is whether different preferences of different genders appear in the choice of job sector and whether this is going in a positive or negative direction in terms of the income situation.

\section{Literature Overview}

Gender differences in remuneration are recorded in all EU countries. On average women have a 15\% lower wage than men (Boll, Lagemann, 2019). A disposable income of households significantly reflects the socio-economic situation of the population of the state concerned (Keeley, 2015). The household or individual disposable income should be taken into account in a measurement of living standards (Burlacu, 2016). Due to the persisting gender pay gap and on average lower remuneration of women, they do not have equal starting conditions to achieve the same living standard as men and this is seen above all in the households of single women and single female parents. As a consequence of this, these households are more prone to the risk of a life of poverty (Kramer et al., 2016). Castellano and Rocca (2014) confirm the occurrence of a pay gap in all European countries, while seeing the friendliest conditions for women on the labour market in terms of equality in remuneration in Scandinavian countries, whereas the situation is the opposite in eastern and southern Europe. Landmesser (2019) verified the occurrence of the gender pay gap in all EU countries and states that gender differences in remuneration mostly occur in countries such as Poland, the Czech Republic, Slovakia, Bulgaria, Hungary, Croatia and others, while indicating that income conditions are more balanced on the labour market in western Europe.

The differences in men's and women's salaries have an effect on income equality, which is the basic characteristic of a healthy society and a necessary consequence of a functioning economic system (Moller et al., 2009). On the other hand, income inequality also brings negative consequences for society in the form of criminality, social unrest, etc. (Kujala et al., 2019). Greig et al. (2007) state that at a time of economic growth income inequality can increase, which has a negative effect on low-income households that often include single female parents. Income differences have a greater impact on low-income households (Landmesser, 2019). Income inequality also has psychological consequences, such as low or no happiness, poor morale or low social cohesion (Buttrick and Oishi, 2017). Roy and Chaudhuri (2008) draw attention to the position of women in society which is affected by income inequality. According to their study, women evaluate their health conditions worse and use medical services less because of their position.

Among the factors significantly affecting income inequality are demographic changes and changes in the structure of society (Chaupain-Guillot and Guillot, 2015). Demographic and socio-economic factors of the individual in particular determine the level of his or her income (Corsi et al., 2016; Aisa et al., 2019; Gradín et al., 2010). Corsi et al. (2016) in connection with remuneration, depending on gender, also talks of another factor, which is 
preference of job positions or employment industries for certain genders on which the wage level is based, i.e. various levels of remuneration in the technology sector in comparison with services for example. She adds that different wages of men and women do not mean gender discrimination, but other preferences of differently evaluated job positions. The choice of job sector and profession, i.e. various preferences of men and women, are the most important factor explaining the gender pay gap (Karamessini, Ioakimoglou, 2007). In gender-based discrimination this concerns refusal of access to equal opportunity among the labour force. In gender discrimination this usually means that women have a lower income for work than men (Loseke, 2017). There are many causes of income influenced by gender. Navarro and Salverda (2019) examined differences in household income based on satisfaction with work activity. They show that men are more satisfied if they bring higher earnings into the household so they demand a job position with higher remuneration. This does not necessarily have to be about discrimination, but about prioritising different job positions at work. In contrast, women require more free time for family and the wage level for them is not the main thing. Duvivier and Narcy (2015) draw attention to the motherhood wage penalty due to child-related career interruptions. Women with children have worse access to management positions and adjusted working conditions.

Further possibilities of why income differences occur according to Navarro and Salverda (2019) is a situation when workers of different gender dispose of the same capital (experience, education, etc.), are assigned different work. Women are usually assigned work on a lower job grade, such as administrative work, whereas men with the same education can perform corporate management activities. Gradín et al. (2010) also draw attention to discrimination against women which is a determining factor for poverty, and add that the risk-of-poverty rate rises for individuals living in a household which depends primarily on women's earnings. Fox et al. (2015) stress that at the present time single-person households predominate among households living with the risk of poverty, including households consisting of a single female parent and children. This does not concern mainly old-age pensioners, as was the case in the past. Likewise, Aisa et al. (2019) talks of the role of gender when measuring the poverty rate, but also sees other determinants of poverty in higher attained education and the work status of the persons in a household. Di Meglio et al. (2018) states that the occurrence of poverty is derived especially from a combination of specific categories of gender, age, economic activity and higher attained education. The effect of gender on the wage level is augmented by motherhood and child care.

Besides the effect of demographic factors on the level of income, there is the influence of factors which apply to actual employment. Xiao (2001) states that the growth of remuneration at work is also related to change of jobs during a career, adult education, technical level of employees and characteristics of job positions that an employer is able to offer. 


\section{Methodology}

The primary data source for this study is the EU-SILC (European Union - Statistics on Income and Living Conditions) survey, specifically of 2019 data. The EU-SILC survey provides detailed data on the income situation of households and individuals, making it possible to identify the demographic and socio-economic factors of households and the individual living in them. This extensive sample of microdata also contains data on the employment of individuals according to the industry of employer's activity (job sector) and its size, on the type of employment contract, the job description of the individual, etc. Besides data on the income situation, the EU-SILC data offers information about the living conditions of households and a subjective evaluation of various spheres of life.

In 2019 the EU-SILC survey was conducted on a total of 260,876 European households and 518,415 individuals took part in it altogether. The EU-SILC survey is compulsory in all European Union states and takes place according to uniform methodology published by Eurostat (Eurostat, 2019). Eurostat also issues uniform methodology for work with these data. Economically active individuals were filtered out of the total number of collected data $(521,391$ individuals), who stated their economic status in the survey as being an "employee". So altogether this involves working with the data taken from 178,878 respondents from all EU countries.

The basic variable, which is based on further calculations and analyses, is the employment income variable which includes the total annual gross employment income of the individual (i.e. annual wage or salary) expressed in Euros for all EU countries. EU-SILC data contain a conversion coefficient which is used as a weight in the conversion of data from a selected sample to the basic sample (i.e. the entire population of the country concerned). The conversion coefficient is taken into account in all conducted analyses.

The ISCO (International Standard Classification of Occupations), which is respected within the framework of the EU-SILC database, is used in order to determine the job sector and job position of individuals.

The dependence of two variables is assessed using contingency tables and tested by the chi-square test with the materiality level of $\alpha=0.05$. The chi-square tested null hypothesis means the independence of variables. If the resulting p-value is lower than the materiality level, the null hypothesis of independence is rejected (Hebák et al., 2015).

The factors affecting employment income and factors affecting gender differences in income are determined by applying the multiple linear regression analysis in which data are entered from respondents of the entire EU. The regression analysis is conducted using the Stepwise method, i.e. by the step-by-step addition of variables, which increase the quality of the model. The quality of the model is assessed by the determination coefficient. The one with the highest determination coefficient is selected as the resulting model. The materiality of the model is tested using the F test with a null hypothesis representing the model's insignificance and materiality level of $\alpha=0.05$.

The multiple linear regression analysis is based on the following general model:

$$
y=\beta_{0}+\beta_{1} x_{1}+\beta_{2} x_{2}+\ldots+\beta_{m} x_{m}+\varepsilon
$$


where $x_{i}$ are independent explanatory variables, $y$ is a dependent explained variable, $\beta_{i}$ are unknown regression parameters, $m$ represents their number and $\varepsilon$ represents the model's random component (Greene, 2018).

To analyse the gender differences in income, the data were complemented by the hypothetical variable $y$. The constructed dependent variable $y$ "Differences in Income" is calculated as follows:

$$
y=\left|\overline{x_{m}}-x_{i}\right|
$$

where $\overline{x_{m}}$ is the weighted arithmetic average of men's employment income and $x_{i}$ is women's employment income for $i=1,2, \ldots, n$.

Abbreviations of EU countries are used as follows: Austria (AT), Belgium (BE), Bulgaria (BG), Cyprus (CY), Czechia (CZ), Germany (DE), Denmark (DK), Estonia (EE), Greece (EL), Spain (ES), Finland (FI), France (FR), Croatia (HR), Hungary (HU), Ireland (IE), Italy (IT), Lithuania (LT), Luxembourg (LU), Latvia (LV), Malta (MT), Netherlands (NL), Poland (PL), Portugal (PT), Romania (RO), Sweden (SE), Slovenia (SI), Slovakia (SK), United Kingdom (UK). IBM SPSS Statistics 27 is used in this study for processing EUSILC data.

\section{Results}

\section{Employment income of men and women in EU countries and gender differences}

Economically active individual, who are employees, are filtered from data of the EU-SILC survey on incomes and living conditions of households. This segment is the subject of interest of this article, which concerns only employees, i.e. the following analysis does not contain the self-employed, long-term unemployed and the sick, etc. Employment incomes and their attained level and inequality are assessed on the basis of the individual's gross wage or salary.

Table 1 offers an overview of employment income in the absolute value. Countries are listed in descending order from the attained highest remuneration differences. The absolutely highest differences in the income of men and women are in the economically highest performing EU countries where there is also a higher price level, etc. But as is seen from the graph (Figure 1), in percentage terms of income differences according to gender, countries such as Finland, Denmark or Luxembourg are not among those where there would be the most difference in the remuneration of women and men within the EU. The data in the graph (Figure 1) shows that the greatest difference found between the gross income of men and women is at 27\% in the Czech Republic, 24\% in Cyprus and followed by Great Britain with 23\%. These are countries with different economic development and different demographic, cultural and social conditions. The least different income difference is in Romania (6\%) and in Slovenia (11\%). Other countries attain a $12-22 \%$ difference. This state of difference in income between men and women leads to the search of the causes of this state. 
Table 1: Average gross employment income in EU countries in Euros monthly

\begin{tabular}{|lccc|lccc|}
\hline & $\begin{array}{c}\text { Average } \\
\text { men's } \\
\text { income }\end{array}$ & $\begin{array}{c}\text { Average } \\
\text { women's } \\
\text { income }\end{array}$ & $\begin{array}{c}\text { Gender } \\
\text { differences }\end{array}$ & $\begin{array}{c}\text { Average } \\
\text { men's } \\
\text { income }\end{array}$ & $\begin{array}{c}\text { Average } \\
\text { women's } \\
\text { income }\end{array}$ & $\begin{array}{c}\text { Gender } \\
\text { differences }\end{array}$ \\
\hline LU & 5841 & 4892 & 949 & ES & 2053 & 1726 & 327 \\
DK & 5036 & 4140 & 896 & LV & 1236 & 966 & 270 \\
FI & 3903 & 3076 & 827 & MT & 2035 & 1781 & 254 \\
IE & 4282 & 3472 & 810 & EE & 1381 & 1139 & 242 \\
UK & 3452 & 2651 & 801 & PT & 1430 & 1200 & 230 \\
AT & 3779 & 3041 & 738 & LT & 1008 & 790 & 218 \\
NL & 4265 & 3571 & 694 & SK & 1010 & 795 & 215 \\
DE & 3630 & 3009 & 621 & HR & 1100 & 894 & 206 \\
FR & 3062 & 2513 & 549 & SI & 1863 & 1660 & 203 \\
BE & 3945 & 3425 & 520 & EL & 1451 & 1254 & 197 \\
CY & 2085 & 1577 & 508 & PL & 1033 & 837 & 196 \\
IT & 2399 & 1982 & 417 & HU & 795 & 664 & 131 \\
SE & 3447 & 3033 & 414 & BG & 613 & 516 & 97 \\
CZ & 1378 & 1001 & 377 & RO & 805 & 757 & 48 \\
\hline
\end{tabular}

Source: own processing of EU-SILC microdata

Figure 1: Percentage difference between men's and women's gross income in the EU in 2019

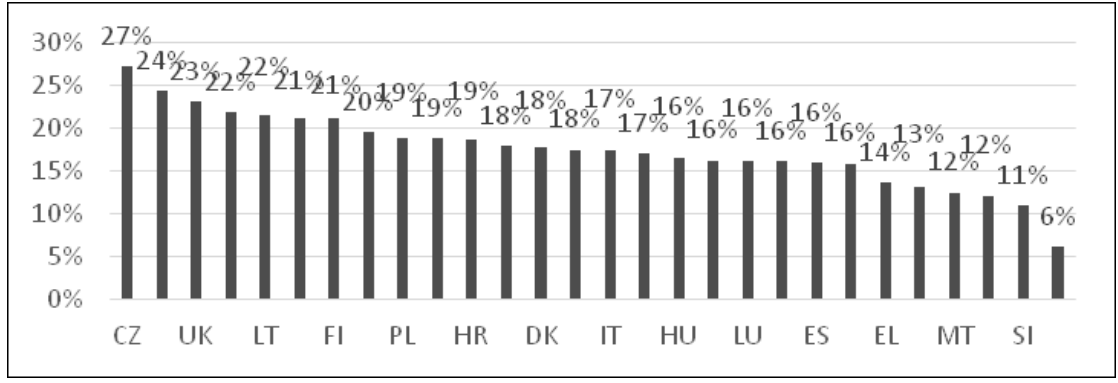

Source: own processing of EU-SILC microdata

It is evident from the following Table 2 that the share of women with an increasing income quintile is decreasing whereas in contrast there is an increase in men with higher quintiles. The data further show that the income level of more than half of employed women $(35 \%+$ $25 \%$ ) ranges within the first two quintiles. If the situation were to be more balanced, there would not be $60 \%$ of women in the first two quintiles, but only $40 \%(20 \%+20 \%)$. 
Table 2: Income quintiles $(Q)$ according to gender representation

\begin{tabular}{|c|c|c|c|c|c|}
\hline & $\begin{array}{c}\text { Share of men } \\
\text { in the quintile } \\
\text { concerned }\end{array}$ & $\begin{array}{c}\text { Share of } \\
\text { women in the } \\
\text { quintile } \\
\text { concerned }\end{array}$ & $\begin{array}{c}\text { Share of the } \\
\text { male } \\
\text { population in } \\
\text { quintiles }\end{array}$ & $\begin{array}{c}\text { Share of the } \\
\text { female } \\
\text { population in } \\
\text { quintiles }\end{array}$ & $\begin{array}{c}\text { Share of } \\
\text { population in } \\
\text { quintiles }\end{array}$ \\
\hline Q 1 & $52 \%$ & $48 \%$ & $27 \%$ & $35 \%$ & $30 \%$ \\
Q 2 & $57 \%$ & $43 \%$ & $23 \%$ & $25 \%$ & $24 \%$ \\
Q 3 & $59 \%$ & $41 \%$ & $25 \%$ & $24 \%$ & $25 \%$ \\
Q 4 & $65 \%$ & $35 \%$ & $12 \%$ & $9 \%$ & $11 \%$ \\
Q 5 & $74 \%$ & $26 \%$ & $13 \%$ & $7 \%$ & $10 \%$ \\
\hline Total & $59 \%$ & $41 \%$ & $100 \%$ & $100 \%$ & $100 \%$ \\
\hline
\end{tabular}

Source: own processing of EU-SILC microdata

It must also be appreciated that this table does not show anything about the differences in the salaries between men and women, but about the representation of men and women in the income quintiles and that in the EU men predominate in the "Full-time Employee" economic activity category. Men account for $59 \%$ of the total number of employees and women account for $41 \%$.

The relationship between the income quintile and gender is significant as the results in Table 3 show.

Table 3: Dependence of the income quintile and gender

\begin{tabular}{|l|rcc|}
\hline & \multicolumn{1}{|c|}{ Value } & df & P-value \\
\hline Pearson Chi-Square & $2,591,547$ & 4 & 0.000 \\
$N$ of Valid Cases & $153,705,678$ & & \\
\hline
\end{tabular}

Source: own processing of EU-SILC microdata

In the Chi-square test the number of cases $(N)$ is 153 million, which after the application of the conversion coefficient from the EU-SILC data, is the actual number of EU inhabitants who are full-time employees. This value is derived from 178,878 respondents, who took part in the survey.

The basic analysis of the gender pay gap (Table 1, Figure 1) makes it possible to express the attained level of men's and women's income in individual countries. These data need to be looked upon as general characteristics which do not corroborate in any way how the attained income values are affected by the series of factors such as gender, age, education, sector in which they work, in what job position, for what period in the working process and others. The EU-SILC survey on household incomes conducted on a great number of households provides identification characteristics of individual members of households and many other characteristics, and creates a database for the study of the effect of these factors. Together with the theoretical findings of authors engaged in this issue, it enables authors to identify factors which affect the differences in income. 


\section{Identification of factors}

\section{Factors affecting the level of employment income}

Given that the difference in employment income according to gender is affected by the level of actual income, it was the factors affecting the level of income there were the first to be analysed. The dependent variable expresses gross employment income. ANOVA is used to verify the choice of regression function, with highly conclusive significance. Based on the verified assumption of the effect of the income group by gender (Table 3), gender entered the regression analysis as the first factor. As the results of the multiple regression analysis show (Table 4), gender is not the only significant factor determining employment income. Further and even more significant factors appear.

The use of the Stepwise method makes it possible to describe what is the effect of each of the independent variables (non-standardised regression coefficient B) and also what is the relative importance or strength of the effect of each of the independent variables (standardised regression coefficient Beta). Table 4 shows that in the selected regression model, independent variables explain $62 \%$ of the variability of the level of employment. We also see that all independent variables are statistically significant (Sig. $<0.05)$. As regards the relative effect, after factors determining the number of months in employment the next in line according to strength of effect are the highest attained education, management position, job sector and others. The "Gender" factor is also significant, but in terms of strength its effect is not in the first place.

What arises from the analysed factors is that income grows with higher attained education as it does with increasing age. What arises from the individual categories of the "Job sector" variable is that the difference in the nature of the job sector causes a difference in income between men and women. If an individual holds a management position he or she earns a higher income. Regression confirms the unequal remuneration of individuals depending on gender. Women have a downward effect on income; there is a greater likelihood that an individual with a growing income is a man. There is a significant effect in other stated factors such as "Number of Months in Unemployment" or "Household Structure" and "Health", which is a subjective evaluation of the healthy condition of the individual. Their dependence is very low and the great scope of the researched sample has contributed to the significance.

Table 4: Factors affecting employment income in the EU

\begin{tabular}{|c|c|c|c|c|c|}
\hline $\mathrm{R}$ & R Square & Adjusted R Square & \multicolumn{3}{|c|}{ Std. Error of the Estimate } \\
\hline 0.79 & 0.62 & 0.62 & \multicolumn{3}{|c|}{17778} \\
\hline \multicolumn{6}{|l|}{ ANOVA } \\
\hline & Sum of Squares & df & Mean Square & $\mathrm{F}$ & Sig. \\
\hline Regression & 143388514070823440 & 12 & 11949042839235286 & 37805381 & 0.000 \\
\hline Residue & 88774983921376272 & 280873721 & 316067248 & & \\
\hline Total & 232163497992199712 & 280873733 & & & \\
\hline
\end{tabular}



and Other Factors on Remuneration of Employees in EU Countries

\begin{tabular}{|c|c|c|c|c|c|}
\hline Independent variables & \multicolumn{2}{|c|}{$\begin{array}{l}\text { Unstandardized } \\
\text { Coefficients }\end{array}$} & $\begin{array}{l}\text { Standardized } \\
\text { Coefficients }\end{array}$ & $t$ & Sig. \\
\hline & B & Std. Error & Beta & & \\
\hline Gender & -2862.2 & 2.2 & -0.16 & 1322.2 & 0.000 \\
\hline Education & 2624.3 & 0.9 & 0.32 & 2946,0 & 0.000 \\
\hline Economic activity & 1338.4 & 1.1 & 0.15 & 1208.3 & 0.000 \\
\hline Age & 0.1 & 0.0 & 0.08 & 1445.6 & 0.000 \\
\hline Household structure & 808.3 & 0.3 & 0.13 & 2493.7 & 0.000 \\
\hline Job sector & -759.4 & 0.4 & -0.21 & 2086.2 & 0.000 \\
\hline $\begin{array}{l}\text { Number of months } \\
\text { of full-time work }\end{array}$ & 2720.7 & 0.4 & 0.78 & 7106.9 & 0.000 \\
\hline $\begin{array}{l}\text { Number of months } \\
\text { of part-time work }\end{array}$ & 1749.7 & 0.5 & 0.23 & 3644.2 & 0.000 \\
\hline $\begin{array}{l}\text { Number of months } \\
\text { in unemployment }\end{array}$ & 465.6 & 0.5 & 0.04 & 922.5 & 0.000 \\
\hline $\begin{array}{l}\text { Type of employment } \\
\text { contract }\end{array}$ & -1998.6 & 3.0 & -0.08 & -672.7 & 0.000 \\
\hline Management position & -3732.6 & 2.6 & -0.236 & 1443.8 & 0.000 \\
\hline Health & 679.9 & 1.3 & 0.057 & 540.7 & 0.000 \\
\hline
\end{tabular}

Source: own processing of EU-SILC microdata, output from IBM SPSS Statistics

\section{Factors affecting difference in men's and women's income}

The EU-SILC survey data and used multiple regression made it possible to identify the factors which have an effect on the differences in income, in the same way as identifying the factors affecting the level of income. A newly created "Difference in Income" variable obtained as the difference of two values - the average income of men and individual values of the income of women - enters the calculations. This obtained data sample, where the newly created variable of the "Difference in Income" from men's and women's employment, was analysed using Stepwise Multiple Regression the results of which are listed in Table 5.

It is evident from Table 5 that $73 \%$ of the variability of the "Differences in Income" dependent variable is explained by the stated independent variables (monitored factors) and the effect of the above factors is statistically conclusive (Sig. < 0.05). It therefore explains the higher percentage of variability than in the income level variable.

The decisive factor (with the highest value of the standardised coefficient) affecting the size of the gender differences in work remuneration is the "Employment Absolute Income" factor determining the size of the absolute value of the achieved income. With the growing absolute income of women the size of the difference decreases as opposed to men's income. In absolute high incomes the differences between men and women are not as great as in lower income levels. 
Table 5: Factors affecting the difference in employment income between men and women

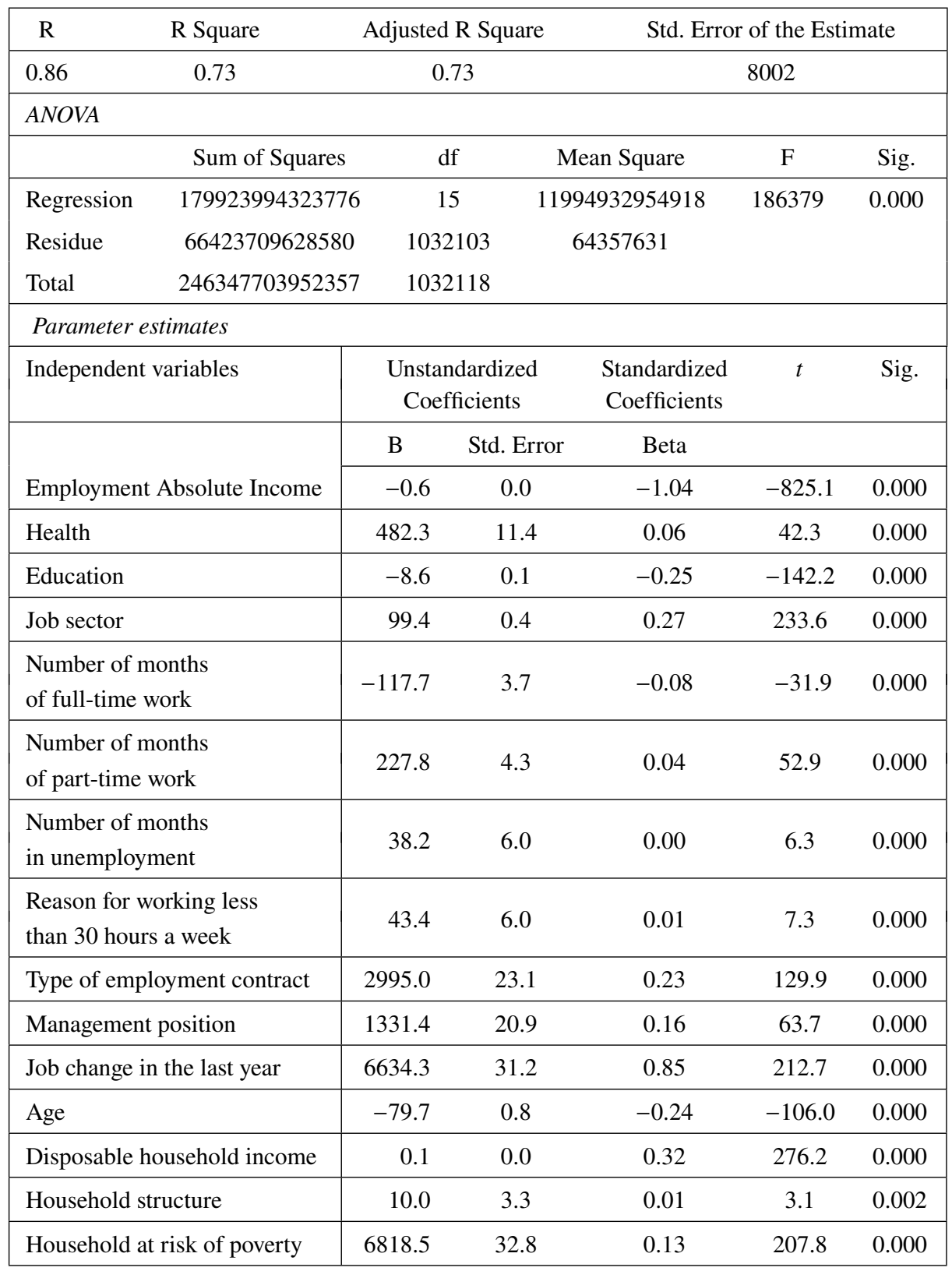

Source: own processing of EU-SILC microdata, output from IBM SPSS Statistics 
Further factors in the sequence according to the rate of the effect on the size of income difference are the demographic factors of "Age" and "Education". Education affects the value of income difference contradirectionally - the lower the education of women the greater the difference in income as opposed to men. The differences in income are higher in younger women, but with an increase in age the differences decrease. This can be explained by women's parental leave after a career start, a return to professional life when women have to catch up with men in work experience as well as in income. The structure of the household can also be mentioned. Greater differences in women's income as opposed to men can be seen in women from a household where there are one and more children. Gender differences are not as great in single-person households or households without children.

The analysis of demographic factors show that the causes of the above facts can be looked for in the setup of social policy parameters such as the length of maternity leave, the option of choosing the amount of working hours due to child care, taking into account child care when determining the level of a pension, etc.

If the factors related to employment it is "Job sector" and "Type of Employment Contract" that have the greatest effect on difference in income. Likewise, if women change jobs the difference becomes greater as opposed to men. The effect decreases with the following factors such as "Number of Months in Unemployment", "Number of Months in Employment", "Management Position" etc. The "Type of Employment Contract" factor shows that women with an employment contract for a limited period are likely to have lower remuneration and this means an increase in income differences. The effect of management positions held by women does not lead to them attaining remuneration for the same management positions held by men. The "Number of Months at Home" means that the longer a woman stays at home the greater the difference in remuneration as opposed to a man. The effect of the factors related to employment is influenced by the type of organisation, form of management of the organisation, etc., within the framework of the legislative measures of the country concerned. Given that the "Job sector" factor after the factors related to actual income and the "Change of Jobs in the Last Year" factor is a further effect, in terms of strength, on income differences in work remuneration, it deserves deeper analysis.

\section{Effect of the "Job sector"}

Verification of the dependence of the choice of job sector and gender is provided in Table 6 . Table 7 shows basic information on the representation of men and women in individual industries, including attained differences in income.

Table 6: Dependence of choice of job sector and gender

\begin{tabular}{|l|rcc|}
\hline & \multicolumn{1}{|c}{ Value } & df & P-value \\
\hline Pearson Chi-Square & $25,314,552$ & 11 & 0.000 \\
$N$ of Valid Cases & $152,605,405$ & & \\
\hline
\end{tabular}

Source: own processing of EU-SILC microdata 
Table 7: Representation of men and women in industries and gender differences in income

\begin{tabular}{|l|cc|c|}
\hline Classified according to ISCO & $\begin{array}{c}\text { Share of } \\
\text { men in the } \\
\text { job sector }\end{array}$ & $\begin{array}{c}\text { Share of } \\
\text { women in the } \\
\text { job sector }\end{array}$ & $\begin{array}{c}\text { Differences } \\
\text { between men's and } \\
\text { women's income }\end{array}$ \\
\hline Legislators and Managers & $66.4 \%$ & $33.6 \%$ & $27 \%$ \\
Science and Technology & $65.9 \%$ & $34.1 \%$ & $22 \%$ \\
Healthcare & $27.6 \%$ & $72.4 \%$ & $28 \%$ \\
Training and Education & $29.8 \%$ & $70.2 \%$ & $26 \%$ \\
Public Administration & $49.9 \%$ & $50.1 \%$ & $34 \%$ \\
Information Technology & $83.0 \%$ & $17.0 \%$ & $23 \%$ \\
Law, Culture and Sport & $44.3 \%$ & $55.7 \%$ & $17 \%$ \\
Administration & $40.4 \%$ & $59.6 \%$ & $35 \%$ \\
Services and Retail & $40.0 \%$ & $60.0 \%$ & $45 \%$ \\
Agriculture, Forestry and Fishing & $78.0 \%$ & $22.0 \%$ & $67 \%$ \\
Craftsmen and Blue-collar Workers & $85.2 \%$ & $14.8 \%$ & $57 \%$ \\
\hline
\end{tabular}

Source: own processing of EU-SILC microdata

It is clear from Table 7 that there are industries where the representation of women predominates. An example of the predominance of women is "Healthcare", "Training and Education" and it is also possible to include "Administration" and "Services and Retail". The large number of women in a job sector does not decide about the size of income differences, but this depends on the distribution of job positions and organisation of work. "Training and Education" and "Healthcare" are state-controlled industries with clearly defined positions. Such defined job positions do not allow difference in men's and women's remuneration in these positions. In contrast, the "Services and Retail" sector, which have a strong representation of women in numbers, the differences in men's and women's income are among the greatest. This is due to the nature of the job sector where there is a predominance of women in lower sales positions or basic job positions. There are only a small number of women represented in jobs of a different grade (head positions) which are more commonly held by men.

The ratio is reversed in the picture of a typically male job sector such as "Information Technology". If women are employed in "Information Technology", their income as opposed to men does not differ that much. In comparison with other industries, average gender differences in income are among the lowest. The situation is different in the "Agriculture, Forestry and Fishing" sector and in the "Craftsmen and Blue-collar Workers" category where the differences in income are the highest at $67 \%$ and $57 \%$. This is due to the technical development required for filling the job positions with men. The differences are so great probably because there is a minimum representation of women and due to the physical demands of the job, so women only perform ancillary work (cleaning, food 
preparation, etc.). There is an equal percentage of men's and women's representation in "Law, Culture and Sport" which also attains the lowest differences in income.

These conclusions need to be complemented by the level of the income situation in individual industries, without the effect of gender. Table 8 shows what income quintiles are attained by individuals from individual industries of the national economy.

Table 8: Income quintiles according to job sector

\begin{tabular}{|l|ccccc|}
\hline \multicolumn{1}{|c|}{ Income quintile } & $\mathbf{1}$ & $\mathbf{2}$ & $\mathbf{3}$ & $\mathbf{4}$ & $\mathbf{5}$ \\
\hline Legislators and Managers & & & & & \\
Science and Technology & $26.6 \%$ & $16.1 \%$ & $16.0 \%$ & $10.6 \%$ & $30.7 \%$ \\
Healthcare & $20.7 \%$ & $17.2 \%$ & $20.2 \%$ & $19.0 \%$ & $23.0 \%$ \\
Training and Education & $32.3 \%$ & $20.7 \%$ & $22.9 \%$ & $13.8 \%$ & $10.3 \%$ \\
Public Administration & $30.9 \%$ & $20.9 \%$ & $22.8 \%$ & $14.6 \%$ & $10.8 \%$ \\
Information Technology & $34.0 \%$ & $18.9 \%$ & $20.6 \%$ & $11.0 \%$ & $15.4 \%$ \\
Law, Culture and Sport & $35.1 \%$ & $14.6 \%$ & $14.4 \%$ & $14.4 \%$ & $21.5 \%$ \\
Administration & $40.0 \%$ & $20.1 \%$ & $20.5 \%$ & $9.2 \%$ & $10.1 \%$ \\
Services and Retail & $31.6 \%$ & $27.0 \%$ & $23.7 \%$ & $10.7 \%$ & $7.1 \%$ \\
Agriculture, Forestry and Fishing & $39.1 \%$ & $28.9 \%$ & $24.6 \%$ & $4.9 \%$ & $2.4 \%$ \\
Craftsmen and Blue-collar Workers & $27.5 \%$ & $27.4 \%$ & $41.4 \%$ & $2.8 \%$ & $0.9 \%$ \\
\hline Total & $30.0 \%$ & $28.4 \%$ & $32.9 \%$ & $8.8 \%$ & $3.9 \%$ \\
\hline
\end{tabular}

Source: own processing of EU-SILC microdata

The factor "Job sector" in which an employee works is conclusively confirmed in the size of the income quintiles attained (Table 9).

Table 9: Dependence of the income quintile and job sector

\begin{tabular}{|l|ccc|}
\hline & Value & df & P-value \\
\hline Pearson Chi-Square & $19,395,930$ & 44 & 0.000 \\
$N$ of Valid Cases & $152,605,405$ & & \\
\hline
\end{tabular}

Source: own processing of EU-SILC microdata

The income situation in individual industries differs significantly, which can be observed in the distribution of job sector incomes in individual quintiles. The fifth quintile has the highest representation for "Legislators and Managers", followed by "Science and Technology" and the "Information Technology" sector. It can be noted that these are industries with an average income difference between men and women. This is because the position of legislator is stated-controlled and men and women have the same pay grade. The "Information Technology" sector also has the same job positions for men and women, but women have a small representation. It is almost unattainable, whether for men 
or women, to be included in the highest income quintile, in four monitored industries, i.e. in "Agriculture, Forestry and Fishing", in "Services and Retail", in "Craftsmen and Blue-collar Workers" and in "Administration". The number representation in the stated industries in the fifth quintile is in ones of percentage. It is also evident from Table 9, and has already been stated several times that in most industries the income of more than half of employees is in the first two quintiles. Thus in the entire EU there is no symmetrical distribution of income, but is left-sided, i.e. with greater number representation of lowincome earners. The lowest incomes are attained in the "Services and Retail" sector, where almost $70 \%$ of employees are in the first and second quintile. This job sector is followed by the "Administration" and "Law, Culture and Sport" industries. The "Healthcare" and "Public Administration" industries approach the most equal distribution approaches.

\section{Conclusion}

A sample of 178,878 economically active individuals who have "Full-time Employee" economic status was filtered from the EU-SILC survey conducted in 2019 in all EU countries. The analyses performed of this sample showed that differences between men's and women's gross income exist in all EU countries, which corresponds to the conclusions of Landmesser (2019), but the generalisation was not confirmed that the highest differences apply above all to countries of the former "Eastern European bloc" countries. The assertion was not confirmed of Castellano and Rocca (2014) that the most equal incomes are in Scandinavian countries. The current EU-SILC data show that the lowest employment income differences between men and women are in Romania (8\%) and Slovenia (10\%). Apart from the low differences in Sweden (12\%) there are low differences in Belgium $(13 \%)$. In contrast, Finland is one of the countries with the highest gender differences in income. The highest values, up to $27 \%$, are attained in the Czech Republic, $22 \%$ in Austria and Lithuania, in most countries the differences range between 10 to $20 \%$.

A conclusive negative dependence was confirmed in all EU countries, which means that women are remunerated with a lower wage than men. Apart from gender, the factors that most affect the level of men's and women's income are "Age", "Education", "Employment sector" and "Management Position". When analysing the gender differences in income, $73 \%$ is explained by verified independent variables. The identification of the strength of the effect of independent variables, including their direction, allowed the use of the Stepwise regression analysis. The strongest effect on the differences in income was found in the "Employment Absolute Income" when the rule is that with growing income the size of the differences increases. Another significant factor according to the strength of the effect is whether a woman changed jobs in the last year. If so, the differences become more profound. The statistically conclusive "Type of Employment Contract" variable shows that women with an employment contract for a limited period are the most likely to have lower remuneration for work and according to the "Number of Months in Unemployment" variable the time spent in unemployment increases the likelihood of a lower wage. The "Education" and "Age" factors have a strong but negative effect. The lower the women's education is the greater the difference as opposed to men's income. With increasing age the differences decrease and this can be caused by women's parental leave after their 
career start. After returning to their profession women have to catch up with men in work experience as well as in income. The "Age" and "Education" factors and their interaction are evident with the distribution of income in individual deciles. Women predominate in the lowest income decile, but there is clearly a greater representation of men from the third decile. Special attention is paid to the "Job sector" factor which has one of the strongest effects on the actual employment income. A conclusive dependence of income from employment and job sector appears. Adam (2020) says the same of the influence of an individual's wage depending on whether he or she is employed in the private sector or in the public sector. Likewise current EU-SILC data also showed that in the public sectors which include "Training and Education" for example, there are no great gender income differences as there are in "Services and Retail" which is part of the private sector. Incomes are lower in the "Services and Retail" sector, which is dominated by women, according to data from the entire EU. 39\% of employees in services and retail fall into the first income quintile. Likewise, in this sector there is a great gender difference in income $(45 \%)$.

We can state that there are gender differences from the results of the analyses and confirmed effect of the verified factors. It is also apparent from the results how many aspects influence the income earned by an employee and that the individual and his or her preferences occupy a significant place in determining the income situation and differences. The actual choice of field by the subject in which he wants to work, what is his or her attitude to life, feeling of satisfaction, luck, what values he or she prioritises and decisions about his or her profession. Such decisions have a continuation and are reflected in the length of education, field of education and those indicated employment industries for concluding employment relationships. This can already be observed in the results of the analyses which conform with the views of Navarro and Salverda (2019) regarding employment preferences in connection with life fulfilment. But the decisions of the subject are made under certain set conditions dependent above all on the parameters of social policy laid down above all by the Labour Code and legislative measures.

Social policy should create such conditions which also respect the different needs and interests of men and women. It should allow women who work and want to work during child care without being discriminated for child care and penalised for going on maternity which is what is also discussed by Duvivier and Narcy (2015). State social policy and the conditions it creates should allow women when fulfilling their maternal duties, not to have to interrupt their professional career but allow them to fulfil their private family objectives. The consequences of setting up parameters need to be considered, and the example used can be maternity and parental leave. The Czech Republic with 3-4 years of parental leave is one of the EU countries with the longest maternity leave and also has the greatest difference in income (27\%). The three or four-year parental leave and time spent outside their profession means that women partly lose their knowledge and expertise whereas men can achieve professional growth and this is connected with income growth. Added to this the measures which are convenient for a certain type of individual, but the lack of the subsequent social policy measures such as the possibility of working part-time during child care, distribution of working hours in professions which allow work from home, 
creation of sufficient child-care facilities, benefit of the effect of the number of children on the calculation of pensions and so on. The presented results show that the social policy of the state concerned has a decisive effect on the position of women in society, i.e. on their remuneration as employees, as well as the verified effect of the analysed factors. In order to set up their parameters it would be expedient to continue with research at a national level.

\section{Acknowledgements}

Supported by the grant No. CZ.02.1.01/0.0/0.0/16_017/0002334 of the Grant Agency Research Infrastructure for Young Scientists.

\section{References}

Adam, A. (2020). Under economic adjustment programs, do private sector wages respond to changes in public wages and employment? Journal of Policy Modeling, 42(6), 1334-1351. Aisa, R., Larramona, G., Peyo, F. (2019). Poverty in Europe by gender: The role of education and labour status. Economic Analysis and Policy, 63, 24-34.

Boll, Ch., Lagemann, A. (2019). The Gender Pay Gap in EU Countries - New Evidence Based on EU-SES 2014 Data. Intereconomics/Review of European Economic Policy, 54(2), 101-105.

Burlacu, M. (2016). The Population' Income, Expenses and Savings as Descriptive Aspects of the Standard of Living. Ovidius University Annals, Series Economic Sciences, 16(2), 175-180.

Buttrick, N., Oishi, S. (2017). The psychological consequences of income inequality. Social \& Personality Psychology Compass, 11(3), e12304.

Castellano, R., Rocca, A. (2014). Gender Gap and Labour Market Participation: A Composite Indicator for the Ranking of European Countries. International Journal of Manpower, 35(3), 345-367.

Di Meglio, E., Kaczmarek-Firth, A., Litwinska, A., Rusu, C. (2018). Living conditions in Europe (1st ed). Luxembourg: Publications Office of the European Union.

Chaupain-Guillot, S., Guillot, O. (2015). Health system characteristics and unmet care needs in Europe: an analysis based on EU-SILC data. The European Journal of Health Economics, 16, 781-796.

Corsi, M., Botti, F., D'Ippoliti, C. (2016). The Gendered Nature of Poverty in the EU: Individualized versus Collective Poverty Measures. Feminist Economics, 22(4), 82-100.

Duvivier, C., Narcy, M. (2015). The Motherhood Wage Penalty and Its Determinants: A Public-Private Comparison. Labour, 29(4), 415-443.

Eurostat (2019). EU statistics on income and living conditions (EU-SILC) methodology. Retrieved November 20, 2020, from https://ec.europa.eu/eurostat/statistics-explained/index.php/EU_statistics_on_income_and_living_conditions_(EU-SILC)_methodology.

Fox, L.,Wimer, C., Garfinkel, I., Kaushal, N., Nam, J., Waldfogel, J. (2015). Trends in Deep Poverty from 1968 to 2011: The Influence of Family Structure, Employment Patterns, and the Safety Net. The Russell Sage Foundation Journal of the Social Sciences, 1(1), 14-34. 
Gradín, C., Del el Río, C., Cantó, O. (2010). Gender wage discrimination and poverty in the EU. Feminist Economics, 16(2), 73-109.

Greene, W. H. (2018). Econometric analysis (8th ed). New York: Pearson.

Greig, A., Hulme, D., Turner, M. (2007). Challenging Global Inequality: Development Theory and Practice in the 21st Century (1st ed). New York: Palgrave Macmillan.

Hebák, P., Jarošová, E., Pecáková, I., Plašil, M. Řezanková, H., Vilikus, O., Vlach, P. (2015). Statistické myšlení a nástroje analýzy dat (2nd ed). Praha: Informatorium.

Keeley, B. (2015). Income Inequality: The Gap between Rich and Poor (1st ed). Paris: OECD Publishing.

Kujala, P., Kallio, J., Niemelä, M. (2019). Income Inequality, Poverty, and Fear of Crime in Europe. Cross-Cultural Research, 52(2), 163-185.

Karamessini, M., Ioakimoglou, E. (2007). Wage determination and the gender pay gap: A feminist political economy analysis and decomposition. Feminist Economics, 13(1), 31-66.

Kramer, K., Myhra, L., Zuiker, V., Bauer, J. (2016). Comparison of Poverty and Income Disparity of Single Mothers and Fathers Across Three Decades: 1990-2010. Gender Issues, 33(1), 22-41.

Landmesser, J. (2019). Differences in income distributions for men and women in the European Union countries. Equilibrium. Quarterly Journal of Economics and Economic Policy, 14(1), 81-98.

Loseke, D. (2017). Social Problems: Constructionist Readings (1st ed). New York: Routledge.

Moller, S., Alderson, A., S., Nielden, D. (2009). Changing Patterns of Income Inequality in U. S. Countries, 1970-2000. American Journal of Sociology, 114(4), 1037-1101.

Navarro, M., Salverda, W. (2019). W. Earner Position and Job and Life Satisfaction: Do Contributions to the Household Income have the Same Effect by Gender and Occupations? Journal of Happiness Studies, 20(7), 2227-2250.

Roy, K., Chaudhuri, A. (2008). Influence of socioeconomic status, wealth and financial empowerment on gender differences in health and health care utilization in later life: evidence from India. Social Science \& Medicine, 66, 1591-1962.

Xiao, J. (2001). Determinants of Employee Salary Growth in Shanghai: An Analysis of Formal Education, On-the-Job Training, and Adult Education with a Three-Level Model. China Review, 1(1), 73-110. 